\title{
PENERAPA METODE HIERARCHICAL CLUSTERING DAN K-MEANS CLUSTERING UNTUK MENGELOMPOKKAN POTENSI LOKASI PENJUALAN LINKAJA
}

\author{
Ivon Fadhila Rahma ${ }^{1}$, Putra Prima Arhandi ${ }^{2}$, Annisa Tufika Firdausi ${ }^{3}$ \\ ${ }^{1,2,3}$ Teknik Informatika, Teknologi Informasi, Politeknik Negeri Malang \\ 1ivon.rahma@gmail.com, ${ }^{2}$ putraprima@polinema.ac.id , ${ }^{3}$ annisa.taufika@polinema.ac.id
}

\begin{abstract}
Abstrak
Tempat atau lokasi yang tepat merupakan salah satu faktor peningkatan strategi bisnis, maka dari itu suatu perusahaan haruslah mengelompakkan mana saja lokasi yang berpotensi bisnis bagi penjualannya. Dan jika harus dikelompokkan secara manual membutuhkan waktu yang sangat lama. Oleh sebab itu, clustering menjadi solusi untuk mengatasi masalah tersebut. Clustering akan mengelompokkan lokasi yang menguntungkan, cukup, dan kurang. Clustering memiliki dua metode, yaitu partisi dan hierarki. Dua metode ini memiliki kelebihan dan kekurangan masing-masing, dan dengan menggabungkan keduanya dapat diperoleh hasil cluster yang lebih baik. Dari hasil cluster dengan menggunakan data penjualan LINKAJA di PT Telekomunikasi, maka diperoleh hasil bahwa gabungan metode Hierarchical Clustering dan K-Means memberikan hasil cluster yang lebih baik dalam pengelompokan lokasi penjualan LINKAJA dengan parameter saldo penjaualan dan umur.
\end{abstract}

Kata kunci : Clustering, Hierarchical Clustering, K-Means Clustering.

\section{Pendahuluan}

LINKAJA adalah wajah baru dari TCASH, layanan keuangan digital ( $e$-wallet) milik Telkomsel, anak usaha PT Telekomunikasi Indonesia (Persero) Tbk atau Telkom. Selain itu, LinkAja merupakan gabungan dari layanan keuangan elektronik milik PT Bank Mandiri (Persero) Tbk dengan E-Cash, UnikQu dari PT Bank Negara Indonesia (Persero) Tbk, dan PT Bank Rakyat Indonesia (Persero) Tbk dengan merek T-Bank. memiliki fungsi yang sama dengan uang tunai sebagai alat pembayaran yang sah, di mana nilainya setara dengan nilai uang tunai yang disetorkan terlebih dahulu ke rekening LINKAJA dan uang yang disetorkan bukanlah bersifat simpanan sebagaimana diatur dalam peraturan perundangundangan perbankan dan oleh karenanya LINKAJA tidak memberikan bunga serta tidak dijamin oleh lembaga Penjamin Simpanan, Telekomunikasi Selular, (2017). Stiker LINKAJA dan saldo LINKAJA bisa dapatkan di banyak tempat salah satunya seperti, Grapari, Alfamart, Indomart, tempat yang berlogo Bang LINKAJA atau Stand LINKAJA yang berada di lokasi-lokasi tertentu. Stand LINKAJA banyak terdapat di beberapa tempat yang sudah bekerja sama dengan Telkomsel. Hal Tersebut untuk mempermudah pengguna LINKAJA dalam menjangkau Stiker LINKAJA atau Top up Saldo tanpa harus membayar pajak seperti saat bertransaksi di Alfamart, Indomart, maupun transaksi melalui Bank.
Saldo LINKAJA pada setiap Stand khusus di PT Telekomunikasi Selular disediakan pada bagian Divisi Broadband Digital Sales (BDS). Namun kebutuhan yang berbeda di setiap lokasi Stand LINKAJA dan proses penambahan saldo saat saldo habis pada setiap Stand, harus melalui penanggung jawab di Divisi BDS. Waktu respon yang tidak menentu mengakibatkan pengisian saldo LINKAJA yang sudah habis pada setiap Stand LINKAJA cukup membutuhkan waktu dan berdampak pada pelanggan yang sedang membeli saldo. Maka dari itu perlu penambahan jumlah saldo pada lokasi Stand LINKAJA yang berpotensi.

Menurut Kotler, et al (2009) place merupakan segala sesuatu yang menunjukkan berbagai kegiatan bisnis untuk membuat produk agar mudah diperoleh oleh pelanggan dan selalu tersedia bagi pelanggan. Apabila berada dalam kondisi bisnis yang memiliki persaingan ketat, faktor pemilihan lokasi menjadi komponen utama yang penting agar usaha yang dijalankan juga dapat bersaing secara efektif, maka perlu adanya lokasi usaha yang strategis dan mudah dijangkau oleh konsumen. Ketepatan pemilihan lokasi merupakan salah satu faktor yang menentukan kesuksesan sebuah usaha. Para pengusaha selalu memiliki pertimbangan yang matang mengenai lokasi sebelum membuka usahanya.

Metode K-Means merupakan metode clustering yang paling sederhana dan umum, B. Santosa, (2007). Hal ini dikarenakan K-Means mempunyai kemampuan mengelompokkan data dalam jumlah yang cukup besar dengan waktu 
komputasi yang relatif cepat dan efisien, K. Arai, et al (2017). Namun, K-means mempunyai mempunyai kelemahan yang diakibatkan oleh penentuan pusat awal cluster. Hasil cluster yang terbentuk dari metode $\mathrm{K}$-means ini sangatlah tergantung pada inisiasi nilai pusat awal cluster yang diberikan, B. Santosa, (2007). Hal ini menyebabkan hasil cluster-nya berupa solusi yang sifatnya local optimal.

Oleh karena itu dalam rangka meningkatkan strategi bisnis, peran PT Telekomunikasi Selular yaitu mengelompokkan lokasi Stand LINKAJA agar dapat mengoptimalkan strategi bisnis dengan cara penambahan saldo LINKAJA, stiker LINKAJA dan penambahan kontrak kerja disetiap tempat yang berpotensi. Hal ini tidak semata mengutamakan keuntungan pihak PT Telekomunikasi Selular saja melainkan mempermudah konsumen dalam mendapatkan pelayanan, fasilitas, dan jangkauan dari PT Telekomunikasi Selular sebagai operator selular terbesar di Indonesia.

Pengelompokan tersebut dapat menggunakan metode pengelompokan dengan algoritma $\mathrm{K}$-Mean dikolaborasikan oleh metode hierarki untuk penentuan pusat awal cluster. Penggabungan antara metode K-Means Clustering dan Hierarchical clustering dikarenakan setiap metode memiliki kekurangan dan kelebihannya masing masing. Untuk metode K-Means Clustering kelebihannya dapat melakukan analisis sampel dalam ukuran yang lebih besar dengan lebih efisien. Selain itu, hanya memiliki sedikit kelemahan pada data outlier, ukuran jarak yang digunakan, dan variabel tak relevan atau variabel yang tidak tepat. Sedangkan kelemahannya adalah untuk titik bakal random lebih buruk dari pada metode hirarkhi. Jika Hierarchical Clustering memiliki kelebihan mempercepat pengolahan dan menghemat waktu karena data yang diinputkan akan membentuk hierarki atau membentuk tingkatan tersendiri sehingga mempermudah dalam penafsiran, namun kelemahan dari metode ini adalah seringnya terdapat kesalahan pada data outlier, perbedaan ukuran jarak yang digunakan, dan terdapatnya variabel yang tidak relevan. Jadi penggabungan keduanya untuk mendapat hasil yang lebih baik.

Dengan data yang sudah di kelompokan menggunakan algoritma $K$-Means, diharapkan dapat mempermudah PT Telekomunikasi Selular dalam meningkatkan strategi pemasaran dengan penambahan saldo LINKAJA, stiker LINKAJA, dan perpanjangan kontrak di setiap tempat berdasarkan tempat yang menguntungkan, cukup, dan kurang.

\section{Landasan Teori}

\subsection{LINKAJA}

LINKAJA adalah uang elektronik yang diselenggarakan oleh Telkomsel yang telah terdaftar dan diawasi oleh Bank Indonesia, memiliki fungsi yang sama dengan uang tunai sebagai alat pembayaran yang sah, di mana nilainya setara dengan nilai uang tunai yang disetorkan terlebih dahulu ke rekening LINKAJA dan uang yang disetorkan bukanlah bersifat simpanan sebagamana diatur dalam peraturan perundang-undangan perbankan dan oleh karenanya LINKAJA tidak memberikan bunga serta tidak dijamin oleh Lembaga Penjamin Simpanan.

Nomor Rekening LINKAJA adalah Nomor Telepon selular dari Pemegang LINKAJA yang tercatat pada saat registrasi, dimana 1 (satu) Rekening LINKAJA hanya berlaku untuk 1 (satu) Nomor Telepon selular, dan juga sebaliknya.

Pengisian Saldo LINKAJA (Cash In/Top Up) dapat dilakukan di titik pelayanan Telkomsel atau Mitra LKD yang telah bekerjasama dengan Telkomsel untuk menyelenggarakan fasilitas Pengisian Saldo (Cash In/Top Up) sesuai dengan ketentuan yang berlaku, atau melalui transfer dana dari rekening uang atau bank lainnya. Transaksi menggunakan LINKAJA hanya dapat dilakukan selama saldo LINKAJA mencukupi, Telekomunikasi Selular, (2017).

Untuk kemudahan Pemegang LINKAJA, dari waktu ke waktu Telkomsel dapat menyediakan media seperti tetapi tidak terbatas pada Aplikasi (LINKAJA Wallet) dan NFC Tag (LINKAJA TAP) penggunan non Telkomsel, USSD (*800\#) khusus untuk pengguna Telkomsel, SMS (2828) yang seluruhnya merupakan satu kesatuan yang tidak terpisahkan dari produk LINKAJA dan informasi dari media akan dijelaskan lebih lanjut dalam website LINKAJA[1].

$$
R(x, y)= \begin{cases}1 & \text { jika } f(x, y)>=T \\ 0 & \text { sebaliknya }\end{cases}
$$

\subsection{Clustering}

Analisis kelompok (cluster analysis) adalah mengelompokkan data (objek) yang didasarkan hanya pada informasi yang ditemukan dalam data yang menggambarkan objek tersebut dan hubungan diantaranya.

Clustering merupakan proses partisi satu set objek data ke dalam himpunan bagian yang disebut dengan cluster. Objek yang di dalam cluster memiliki kemiripan karakteristik antar satu sama lainnya dan berbeda dengan cluster yang lain. Partisi tidak dilakukan secara manual melainkan dengan suatu algoritma clustering. Oleh karena itu, clustering sangat berguna dan bisa menemukan group atau kelompok yang tidak dikenal dalam data. Clustering banyak diguakan dalam berbagai aplikasi seperti misalnya pada business intelligence, pengenalan pola citra, web search, bidang ilmu biologi, dan untuk keamanan (security), Edy Irwansyah, et al.

\subsection{Hierarchical Clustering}

Pada hierarchical clustering data dikelompokkan melalui suatu bagan yang berupa hirarki, dimana 
terdapat penggabungan dua grup yang terdekat disetiap iterasinya ataupun pembagian dari seluruh set data kedalam cluster.

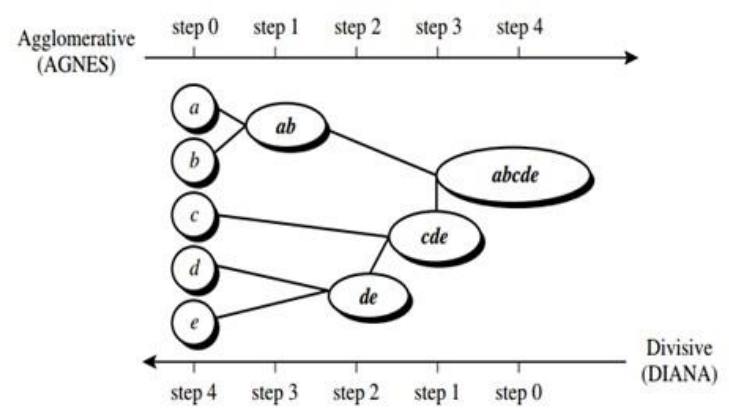

Gambar 1. Hierarchical Clustering

(Sumber: Han, et al, 2012)

Langkah melakukan Hierarchical clustering, Han, J, et al (2012):

1. Identifikasi item dengan jarak terdekat

2. Gabungkan item itu kedalam satu cluster

3. Hitung jarak antar cluster

4. Ulangi dari awal sampai semua terhubung

\section{$2.4 \quad$ K-Means Clustering}

K-Means adalah suatu teknik pengelompokan data yang mana keberadaan tiap-tiap titik data dalam suatu cluster ditentukan oleh derajat keanggotaan. Teknik ini pertama kali diperkenalkan oleh Jim Bezdek pada tahun 1981, Kusumadewi, et al (2010).

K-Means merupakan algoritma clustering yang berulangulang. Algoritma $\mathrm{K}$-Means dimulai dengan pemilihan secara acak $\mathrm{K}, \mathrm{K}$ disini merupakan banyaknya cluster yang ingin dibentuk. Kemudian tetapkan nilai $\mathrm{K}$ secara random, untuk sementara nilai tersebut menjadi pusat dari cluster atau bisa disebut dengan centroid menggunakan rumus hingga ditemukan jarak yang paling dekat dari setiap data dengan centroid. Klasifikasikan setiap data berdasarkan kedeketannya dengan centroid. Lakukan langkah tersebut hingga nilai centroid tidak berubah (stabil), Rismawan, T (2008).

Algoritma K-Means adalah algoritma yang mempartisi data ke dalam cluster-cluster sehingga data yang memiliki kemiripan berada pada satu cluster yang sama dan data yang memiliki ketidaksamaan berada pada cluster yang lain. Sarwono mengemukakan secara lebih detail, algoritma $\mathrm{K}$-Means adalah sebagai berikut (Sarwono Y. T. (n.d) :

a. Menentukan K sebagai jumlah kluster yang ingin di bentuk.

b. Membangkitkan nilai random untuk pusat cluster awal (centroid) sebanyak K

c. Menghitung jarak setiap data input terhadap masing - masing centroid menggunakan rumus jarak Euclidean (Euclidean Distance) hingga ditemukan jarak yang paling dekat dari setiap data dengan centroid. Berikut adalah persamaan Euclidian Distance:

$$
d\left(x_{i}, \mu_{j}\right)=\sqrt{\sum\left(x_{i}-\mu_{j}\right)^{2}}
$$

Dimana :

$\mathrm{x}_{\mathrm{i}} \quad$ : Data kriteria,

$\mu_{\mathrm{j}} \quad$ : Centroid pada cluster ke- $\mathrm{j}$

d : Mengklasifikasikan setiap data

berdasarkan kedekatannya dengan centroid (jarak terkecil).

e. Memperbaharui nilai centroid. Nilai centroid baru di peroleh dari rata-rata cluster yang bersangkutan dengan menggunakan rumus: Dimana:

$$
\mu_{j}(t+1)=\frac{1}{N_{s j}} \sum_{j \in S_{j}} x_{j}
$$

$\mu \mathrm{j}(\mathrm{t}+1) \quad: \quad$ Centroid baru pada iterasi ke $(\mathrm{t}+1) \mathrm{Nsj}$ : $\quad$ Banyak data pada cluster $\mathrm{Sj}$.

f. Melakukan perulangan dari langkah hingga e, sampai anggota tiap cluster tidak ada yang berubah.

Jika langkah $\mathrm{f}$ telah terpenuhi, maka nilai pusat cluster $(\mu \mathrm{j})$ pada iterasi terakhir akan digunakan sebagai parameter untuk menentukan klasifikasi data (Sarwono).

\subsection{Klasifikasi}

Klasifikasi adalah proses untuk menemukan model atau fungsi yang menjelaskan atau membedakan konsep atau kelas data dengan tujuan untuk memperkirakan kelas yang tidak diketahui dari suatu objek. Dalam pengklasifikasian data terdapat dua proses yang dilakukan yaitu:

a. Proses training

Pada proses training digunakan training set yang telah diketahui label-labelnya untuk membangun model atau fungsi.

b. Proses testing

Untuk mengetahui keakuratan model atau fungsi yang akan dibangun pada proses training, maka digunakan data yang disebut dengan testing set untuk memprediksi label-labelnya.

Klasifikasi dokumen adalah pemberian kategori yang telah didefinisikan kepada dokumen yang belum memiliki kategori. Mengklasifikasi dokumen merupakan salah satu cara untuk mengorganisasikan dokumen. Dokumen-dokumen yang memiliki isi yang sama akan dikelompokkan ke dalam kategori yang sama. Dengan demikian, orang-orang yang melakukan pencarian informasi dapat dengan mudah melewatkan kategori yang tidak relevan dengan informasi yang dicari atau yang tidak menarik perhatian. 
Peningkatan jumlah dokumen yang begitu pesat telah mendorong berkembangnya metode pengklasifikasian secara otomatis. Metode ini dapat melakukan klasifikasi dengan cara belajar dari sekumpulan contoh dokumen yang telah diklasifikasi sebelumnya. Keuntungan dari metode ini adalah dapat menghemat waktu kerja dan memperoleh hasil yang lebih baik. Metode ini adalah metode support vector machine.

\section{Metodologi \\ 3.1 Data Set}

Metode pengambilan data pada penyusunan penulisan ini, adalah:

a. Studi literatur dengan tujuan:

- Mempelajari dan memahami algoritma Hierarchical Clustering dan K-Means dalam data mining dengan mengumpulkan literatur yang berkaitan, yang didapat dari beberapa referensi-referensi, jurnal-jurnal, melalui buku ataupun website.

- Mempelajari hal yang dapat meningkatkan strategi bisnis.

- Mengetahui data transaksi LINKAJA di beberapa tempat.

b. Pengumpulan data melalui GraPARI Telkomsel Malang.

- Pengumpulan data transaksi LINKAJA yang sudah tercatat di GraPARI Telkomsel Malang.

- Pengumpulan data dengan wawancara untuk mendapatkan data seakurat mungkin. Pengumpulan data dilakukan sesuai dengan sumber dan jenis data yang diperlukan.

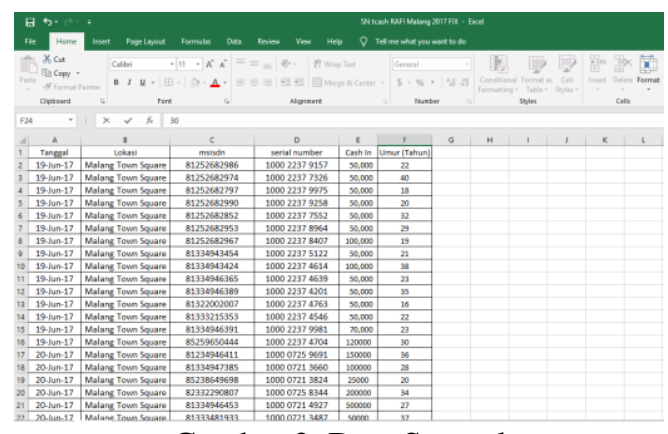

Gambar 2. Data Sampel

\subsection{Proses Clustering}

Berikut ini adalah tahapan pengolahan data pada penerapan metode hierarchical clustering dan K-Means clustering untuk mengelompokkan potensi lokasi penjualan LINKAJA mulai dari start untuk menghitung titik pusat dengan menggunakan hierarchical clustering hingga menemukan titik pusat pada tiga kelompok dan di lanjutkan menghitungan dengan metode K-Means dengan pusat yang telah dihitung sebelumnnya, hingga menghasilkan anggota sesuai dengan kelompoknya yaitu kelompok menguntungkan, cukup, dan kurang. Proses tersebut ditunjukkan seperti Gambar 3:

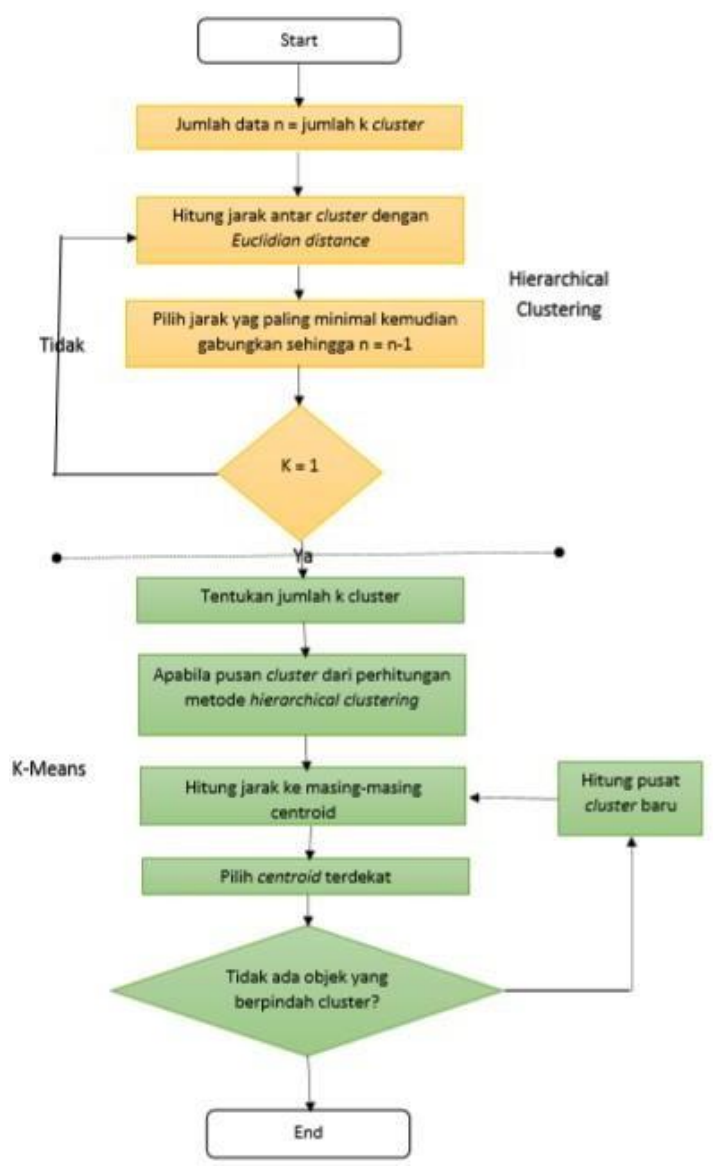

Gambar 3. Flowchart Kombinasi metode Hierarchical clustering dan K-Means clustering

\section{Hasil dan Pengujian \\ 4.1 Hasil}

\section{LOG IN}

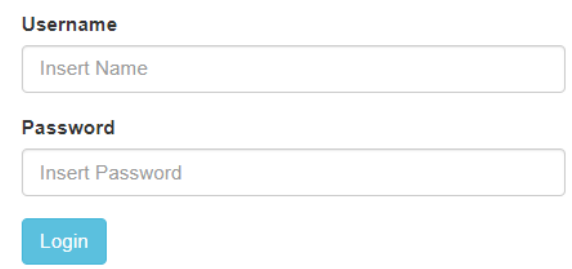

Gambar 4. Tampilan Form Login

Jika didalam form manajemen data lokasi terdapat banyak fitur untuk mengelolah data seperti fungsi insert, update, delete data lokasi penjualan saldo LINKAJA ditunjukkan pada Gambar 5. 

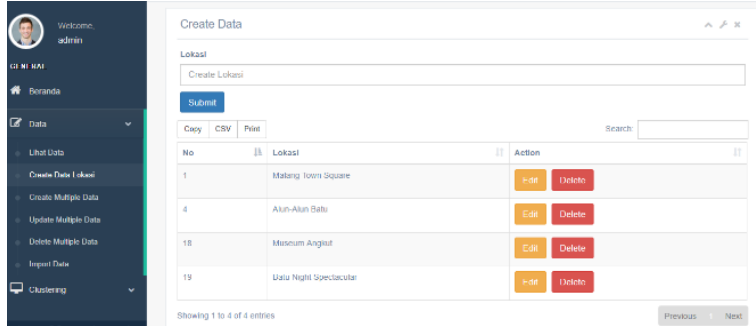

Gambar 5. Form Manajemen Data Lokasi

Jika didalam form manajemen data penjualan saldo LINKAJA terdapat banyak fitur untuk mengelolah data seperti fungsi insert, update, delete data lokasi penjualan saldo LINKAJA ditunjukkan pada Gambar 6.
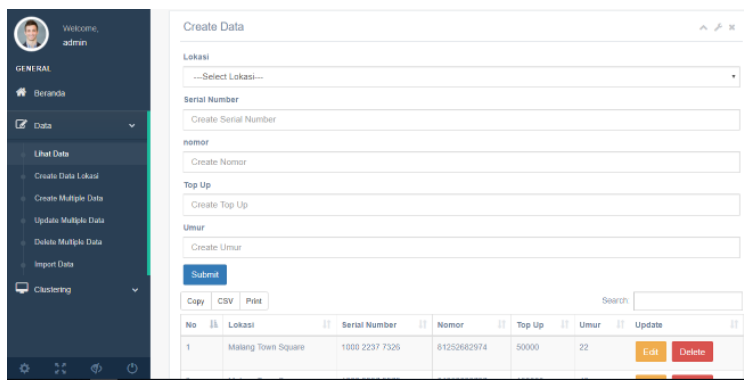

Gambar 6. Form Manajemen Data Penjualan saldo LINKAJA

Form create multiple data digunakan untuk menampahkan lebih banyak secara langsung dan di tunjukkan pada Gambar 7.
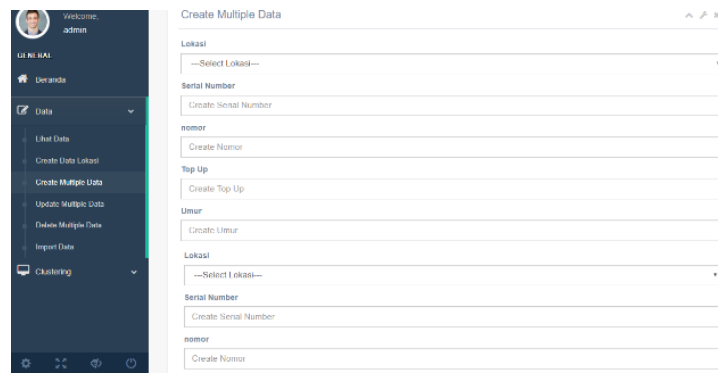

Gambar 7. Create Multiple Data

Halaman delete multiple data adalah halaman untuk menghapus data penjualan saldo LINKAJA secara bersamaan tanpa harus menghapus satu persatu. Ditunjukkan pada Gambar 8.

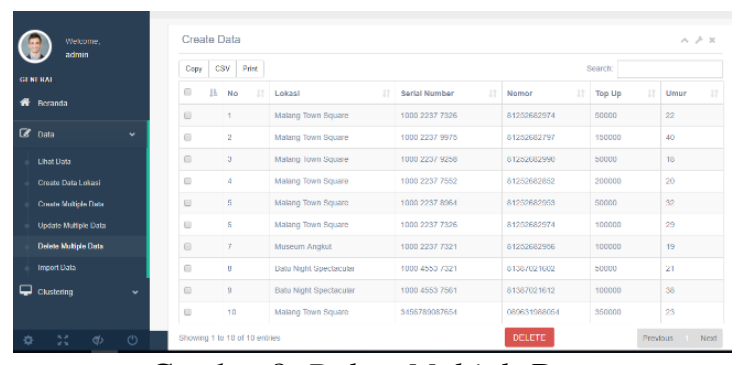

Gambar 8. Delete Multiple Data
Halaman Import Data adalah fasilitas untuk admin dalam menambahkan data dari excel ke database dan menampilkannya ke sistem. Ditunjukkan pada Gambar 9.
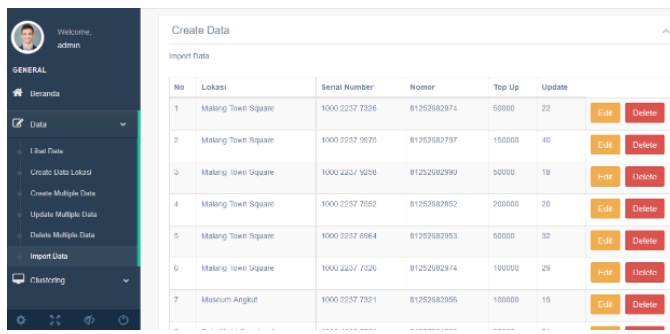

Gambar 9. Import Data

Tampilan Proses Hierarchical Clustering adalah form untuk melihat hasil mencari data tengah untuk dilanjutkan di proses clustering menggunakan metode K-Means. Data tengah untuk data tahun 2017 ditunjukkan pada Gambar 10 dan data tengah untuk data tahun 2018 ditunjukkan pada Gambar 11.

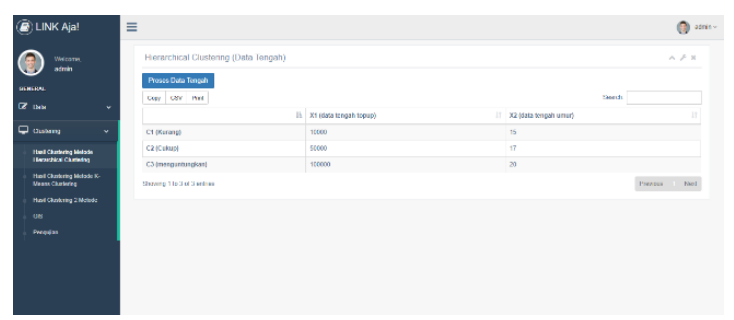

Gambar 10. Tampilan Proses Hierarchical Clustering Data Tahun 2017

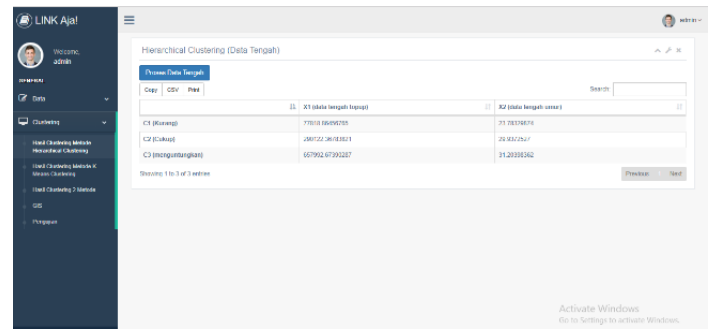

Gambar 11. Tampilan Proses Hierarchical Clustering Data Tahun 2018

Tampilan Proses K-Means Clustering adalah form untuk melihat hasil proses clustering menggunakan metode K-Means. Pada Gambar 12 dan Gambar 13 menjukkan hasil persentase mulai dari yang kurang, cukup, dan menguntungkan pada setiap lokasi sesuai data yang sudah dilakukan proses clustering.

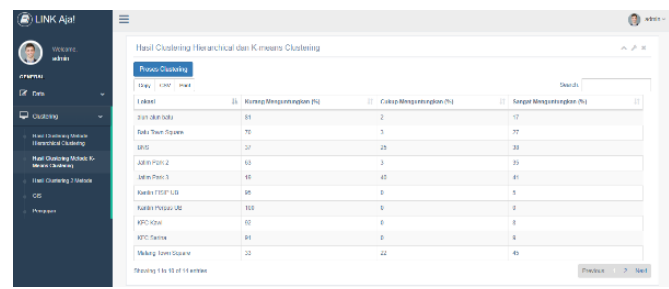

Gambar 12. Tampilan Proses K-Means Clustering Data Tahun 2017 

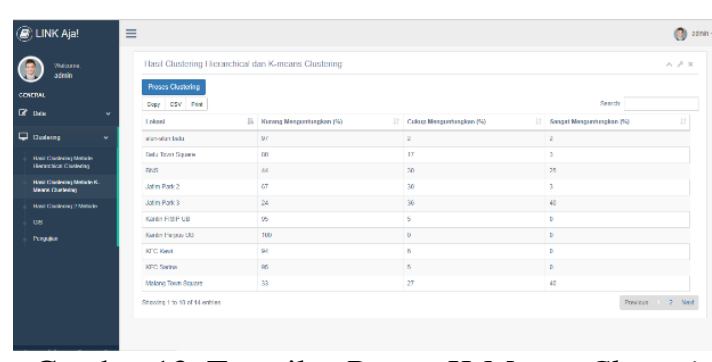

Gambar 13. Tampilan Proses K-Means Clustering Data Tahun 2018

Tampilan Geographic Information System disini adalah berisi tentang lokasi tempat penjualan LINKAJA dan persentase menguntungkan, cukup, dan kurang. Ditunjukkan pada Gambar 14.
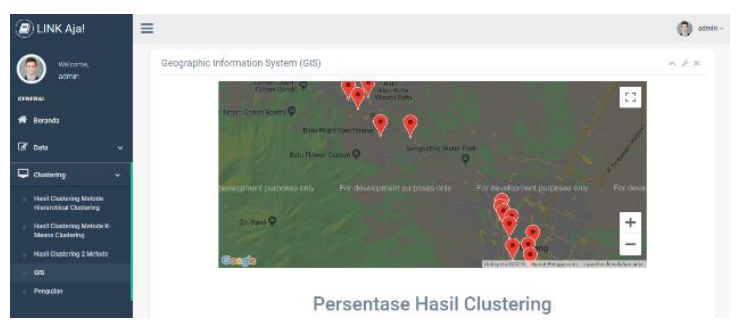

Gambar 14. Tampilan Geographic Information System

Tampilan Tampilan Hasil Pengujian adalah form untuk melihat persentase akurasi yang dihasilkan dari sistem ini. Hasil Pengujian untuk data tahun 2017 ditunjukkan pada Gambar 15 dan Hasil Pengujian untuk data tahun 2018 ditunjukkan pada Gambar 16.
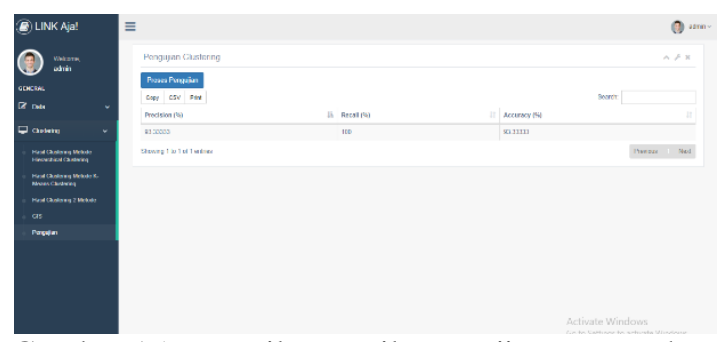

Gambar 15. Tampilan Hasil Pengujian Data Tahun 2017

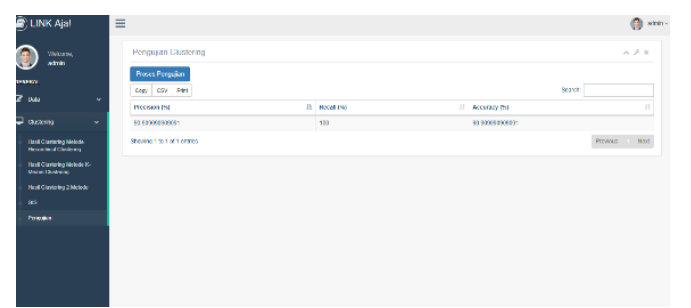

Gambar 16. Tampilan Hasil Pengujian Data Tahun 2018

\subsection{Pengujian}

\subsubsection{Pengujian Proses}

Pengujian merupakan cara atau teknik untuk menguji perangkat lunak, mempunyai mekanisme untuk menentukan data uji yang dapat menguji perangkat lunak secara lengkap dan mempunyai kemungkinan tinggi untuk menemukan kesalahan. Berikut ini merupakan pengujian yang dilakukan di dalam system penerapan metode hierarchical clustering dan k-means clustering untuk mengelompokkan potensi lokasi penjualan LINKAJA.

\subsubsection{Pengujian Black Box}

Pengujian ini dilakukan untuk menemukan fungsi-fungsi yang tidak benar atau hilang, kesalahan interface, kesalahan dalam struktur data atau akses database eksternal, kesalahan kinerja, inisialisasi dan kesalahan terminasi.

Pengujian fungsi-fungsi pada penerapan metode hierarchical clustering dan k-means clustering untuk mengelompokkan potensi lokasi penjualan LINKAJA. Berikut hasil sekenario pengujian fungsionalitas.

Tabel 1. Hasil Pengujian Fungsionlitas

\begin{tabular}{|c|c|c|c|c|}
\hline No & $\begin{array}{c}\text { Pola } \\
\text { Pengujian }\end{array}$ & $\begin{array}{c}\text { Hasil yang } \\
\text { diharapkan }\end{array}$ & $\begin{array}{c}\text { Hasil } \\
\text { yang } \\
\text { terjadi }\end{array}$ & Ket. \\
\hline 1 & $\begin{array}{l}\text { Melakukan } \\
\text { login untuk } \\
\text { hak akses } \\
\text { admin }\end{array}$ & $\begin{array}{l}\text { Ketika } \\
\text { mmbuka } \\
\text { halaman } \\
\text { awal website } \\
\text { akan } \\
\text { menampilka } \\
\text { n form login }\end{array}$ & $\begin{array}{l}\text { Ketika } \\
\text { membu } \\
\text { ka } \\
\text { halama } \\
\text { n awal } \\
\text { website } \\
\text { akan } \\
\text { menam } \\
\text { pilkan } \\
\text { form } \\
\text { login }\end{array}$ & Berhasil \\
\hline 2 & $\begin{array}{l}\text { Mengisi } \\
\text { username } \\
\text { dan } \\
\text { password }\end{array}$ & $\begin{array}{l}\text { Mengisi } \\
\text { username } \\
\text { dan } \\
\text { password } \\
\text { untuk masuk } \\
\text { ke hak akses } \\
\text { admin, jika } \\
\text { salah akan } \\
\text { muncul } \\
\text { "login gagal" }\end{array}$ & $\begin{array}{l}\text { Mengisi } \\
\text { userna } \\
\text { me dan } \\
\text { passwo } \\
\text { d untuk } \\
\text { masuk } \\
\text { ke hak } \\
\text { akses } \\
\text { admin, } \\
\text { jika } \\
\text { salah } \\
\text { akan } \\
\text { muncul } \\
\text { "login } \\
\text { gagal" }\end{array}$ & Berhasil \\
\hline 3 & $\begin{array}{l}\text { Melakukan } \\
\text { proses } \\
\text { menejemen } \\
\text { insert data } \\
\text { penjualan } \\
\text { saldo } \\
\text { LINKAJA } \\
\text { pada hak } \\
\text { akses } \\
\text { admin }\end{array}$ & $\begin{array}{l}\text { Melakukan } \\
\text { insert } \\
\text { manual, } \\
\text { multiple } \\
\text { insert, dan } \\
\text { insert data } \\
\text { dari excel } \\
\text { pada data } \\
\text { penjualan } \\
\text { saldo } \\
\text { LINKAJA }\end{array}$ & $\begin{array}{l}\text { Jika } \\
\text { salah } \\
\text { akan } \\
\text { melaku } \\
\text { kan } \\
\text { update } \\
\text { "data } \\
\text { gagal } \\
\text { ditamba } \\
\text { hkan" } \\
\text { jika } \\
\text { benar }\end{array}$ & Berhasil \\
\hline
\end{tabular}




\begin{tabular}{|c|c|c|c|c|}
\hline No & $\begin{array}{c}\text { Pola } \\
\text { Pengujian }\end{array}$ & $\begin{array}{c}\text { Hasil yang } \\
\text { diharapkan }\end{array}$ & $\begin{array}{c}\text { Hasil } \\
\text { yang } \\
\text { terjadi }\end{array}$ & Ket. \\
\hline & & & $\begin{array}{l}\text { tampil " } \\
\text { data } \\
\text { berhasil } \\
\text { ditamba } \\
\text { hkan" }\end{array}$ & \\
\hline 4 & $\begin{array}{l}\text { Melakukan } \\
\text { proses } \\
\text { menejemen } \\
\text { update data } \\
\text { penjualan } \\
\text { saldo } \\
\text { LINKAJA } \\
\text { pada hak } \\
\text { akses } \\
\text { admin }\end{array}$ & $\begin{array}{l}\text { Melakukan } \\
\text { update } \\
\text { manual dan } \\
\text { multiple } \\
\text { update pada } \\
\text { data } \\
\text { penjualan } \\
\text { saldo } \\
\text { LINKAJA }\end{array}$ & $\begin{array}{l}\text { Jika } \\
\text { salah } \\
\text { akan } \\
\text { melaku } \\
\text { kan } \\
\text { update } \\
\text { "data } \\
\text { gagal } \\
\text { diupdat } \\
\text { e" jika } \\
\text { benar } \\
\text { tampil " } \\
\text { data } \\
\text { berhasil } \\
\text { diupdat } \\
\text { e" }\end{array}$ & Berhasil \\
\hline 5 & $\begin{array}{l}\text { Melakukan } \\
\text { proses } \\
\text { menejemen } \\
\text { delete data } \\
\text { penjualan } \\
\text { saldo } \\
\text { LINKAJA } \\
\text { pada hak } \\
\text { akses } \\
\text { admin }\end{array}$ & $\begin{array}{l}\text { Melakukan } \\
\text { delete } \\
\text { manual dan } \\
\text { multiple } \\
\text { delete pada } \\
\text { data } \\
\text { penjualan } \\
\text { saldo } \\
\text { LINKAJA }\end{array}$ & $\begin{array}{l}\text { Jika } \\
\text { salah } \\
\text { akan } \\
\text { melaku } \\
\text { kan } \\
\text { update } \\
\text { "data } \\
\text { gagal } \\
\text { dihapus' } \\
\text { 'jika } \\
\text { benar } \\
\text { tampil " } \\
\text { data } \\
\text { berhasil } \\
\text { dihapus' }\end{array}$ & Berhasil \\
\hline 6 & $\begin{array}{l}\text { Melakukan } \\
\text { proses cari } \\
\text { di } \\
\text { manajemen } \\
\text { data }\end{array}$ & $\begin{array}{l}\text { Berhasil } \\
\text { menampilka } \\
\text { n sesuai apa } \\
\text { yang dicari }\end{array}$ & $\begin{array}{l}\text { Berhasi } \\
1 \\
\text { menam } \\
\text { pilkan } \\
\text { sesuai } \\
\text { apa } \\
\text { yang } \\
\text { dicari }\end{array}$ & Berhasil \\
\hline
\end{tabular}

\subsubsection{Pengujian Akurasi Sistem (Accuracy,} Precision, Recall)

Uji coba ini dilakukan untuk menguji tingkat akurasi sistem dengan menghitung persentase data yang sesuai. Setelah dilakukan proses clustering dengan menggunakan metode Hierarchical Clustering dan K-means Clustering selanjutnya di lakukan pelabelan pada setiap cluster mulai dari yang kurang, cukup, dan menguntungkan. Setelah itu untuk mengetahui keberhasilan algoritma dalam proses klasifikasi maka akan dibandingkan hasil klasifikasi yang dilakukan oleh sistem dengan hasil klasifikasi yang dilakukan oleh pakar. Perbandingan tersebut akan dihitung tingkat kebenaranannya menggunakan accuracy, precision dan recall.
Dalam pengujian ini menggunakan 1099 data Tahun 2017 dan 1029 data Tahun 2018 penjualan LINK AJA oleh PT. Telekomunikasi Selular. Berikut rincian data yang akan diuji ditunjukkan Tabel 1.

Tabel 2. Pengujian Data Penjualan LINKAJA Tahun 2017 dan 2018

\begin{tabular}{|c|c|c|c|}
\hline \multirow{2}{*}{ Data } & \multicolumn{3}{|c|}{ Pengujian } \\
\cline { 2 - 4 } & Accuracy & Precision & Recall \\
\hline 2017 & $93.33 \%$ & $93.33 \%$ & $100 \%$ \\
\hline 2018 & $90,909 \%$ & $90,909 \%$ & $100 \%$ \\
\hline
\end{tabular}

Berdasarkan rincian data uji pada Table 2 pengujian data pada tahun 2017 diperoleh nilai accuracy sebesar 93.33\%, nilai Precision sebesar 93.33\%, dan Recall sebesar $100 \%$. Sedangkan pada tahun 2018 diperoleh nilai accuracy sebesar 90,909\%, nilai Precision sebesar 90,909\%, dan Recall sebesar 100\%.

\subsubsection{Pengujian Performance}

Uji Coba ini dilakukan untuk menguji performance dari aplikasi yang telah dibuat dengan menghitung banyak iterasi yang ada di proses KMeans clustering. Untuk mengetahui performance yang dihasilkan sistem menggunakan metode Hierarchical Clustering dan K-Means Clustering ini, maka akan dibandingan banyak iterasi ketika proses cluster menggunakan K-Means dengan metode hierarchical clustering untuk menentukan titik pusat, dan banyak iterasi ketika proses cluster menggunakan $\mathrm{k}$-means dengan pemilihan titik pusat yang random. Berikut hasil pengujian performance ditunjukkan pada Tabel 3.

Tabel 3. Hasil Pengujian Performance

\begin{tabular}{|c|c|c|}
\hline \multirow{2}{*}{ Data } & \multicolumn{2}{|c|}{ Pengujian Performance } \\
\cline { 2 - 3 } & $\begin{array}{c}\text { Menggunakan } \\
\text { Hierarchical }\end{array}$ & $\begin{array}{c}\text { Tanpa } \\
\text { Menggunakan } \\
\text { Hierarchical }\end{array}$ \\
\hline 2017 & 1 iterasi & 18 iterasi \\
\hline 2018 & 1 iterasi & 23 iterasi \\
\hline
\end{tabular}

Berdasarkan rincian hasil pengujian performance pada table 6.3 dengan menggunakan data pada tahun 2017 sejumlah 1099 data didapatkan iterasi proses K-Means clustering menggunakan hirarchical clustering untuk menentukan titik pusat sebanyak 1 iterasi dan banyak iterasi proses k-means clustering tanpa menggunakan hirarchical clustering sebanyak 18 iterasi. Sedangkan dengan menggunakan data pada tahun 2018 sejumlah 1029 data didapatkan iterasi proses K-Means clustering menggunakan hirarchical clustering untuk menentukan titik pusat sebanyak 1 iterasi dan banyak iterasi proses K-Means clustering tanpa menggunakan hirarchical clustering sebanyak 23 iterasi. 


\section{Kesimpulan dan Saran 5.1 Kesimpulan}

Adapun kesimpulan yang dapat diambil dari hasil penelitian yang dilakukan mengenai penerapan metode hierarchical clustering dan K-Means clustering untuk mengelompokkan potensi lokasi penjualan LINKAJA adalah sebagai berikut.

a. Hasil clustering menggunakan metode K-Means clustering dengan metode hierarchical clustering untuk menentukan titik pusatnya menghasilnya iterasi yang lebih sedikit sehingga mempercepat proses.

b. Dari hasil pengujian akurasi penerapan metode hierarchical clustering dan K-Means clustering untuk mengelompokkan potensi lokasi penjualan LINKAJA pada data tahun 2017 lokasi yang menguntungkan adalah Malang Town Square, Jatim Park 3, Batu Night Spectaculer dan lokasi yang cukup adalah Museum Angkut dan lokasi yang kurang adalah Kantin Fakultas Ilmu Sosial dan Ilmu Politik Universitas Brawijaya, Kantin Perpustakaan Universitas Brawijaya, Batu Town Square, Universitas Negeri Malang, KFC Kawi, KFC Sarina, Mc Donald Watugong, Mc Donald Kayutangan, Jatim Park 2, Alun - alun Kota Batu. Sedangkan data tahun 2018 lokasi yang menguntungkan adalah Malang Town Square, Jatim Park 3 dan lokasi yang cukup adalah Museum Angkut dan lokasi yang kurang adalah Kantin Fakultas Ilmu Sosial dan Ilmu Politik Universitas Brawijaya, Kantin Perpustakaan Universitas Brawijaya, Batu Town Square, Batu Night Spectaculer, Universitas Negeri Malang, KFC Kawi, KFC Sarina, Mc Donald Watugong, Mc Donald Kayutangan, Jatim Park 2, Alun alun Kota Batu.

c. Hasil klasterisasi metode hierarchical clustering dan K-Means clustering untuk mengelompokkan potensi lokasi penjualan linkaja memperoleh tingkat keakurasian system 93,33\% pada tahun 2017 dan memperoleh tingkat keakurasian system $90,90 \%$ pada tahun 2018 berdasarkan 3 kelompok yang diuji.

\subsection{Saran} yaitu:

Berdasarkan penelitian hal yang disarankan

a. Penelitian ini masih dapat dikembangkan lagi menjadi sistem yang lebih lengkap lagi karena masih banyak data pendukung responden yang dapat dianalisis dari hasil clustering.

b. Sistem disarankan menggunakan desktop karena proses clustering nya yang lama jika menggunakan php.

\section{Daftar Pustaka:}

B. Santosa. (2007): Data Mining. Teknik Pemanfaatan Data untuk Keperluan Bisnis, First Edition ed. Yogyakarta: Graha Ilmu

Edy Irwansyah, Muhammad Faisal. Advanced Clustering Teori dan Aplikasi

Han, J., Kamber, M., Pei, J. (2012): Data Mining Concept and Techniques, 3rd Ed Morgan Kaufmann-Elsevier, Amsterdam

Kotler, Philip dan Kevin Lane Keller. (2009): Manajemen Pemasaran. Terjemahan oleh Benyamin Molan. Edisi Keduabelas. Jilid 1. Jakarta: Indeks

Kusumadewi dan Purnomo. (2010): Aplikasi Logika Fuzzy untuk mendukung keputusan. Yogyakarta: Graha Ilmu

K. Arai and A. R. Barakbah. (2007): Hierarchical Kmeans: an algorithm for centroids initialization for Kmeans.

Rismawan, T. (2008): Aplikasi K-Means Untuk Pengelompokkan Mahasiswa

Sarwono, Y. T. (n.d.). Aplikasi Model Jaringan Syaraf Tiruan Dengan Radial Basis Function Untuk Mendeteksi Kelainan Otak (Stroke Infark). Jurnal Sistem Informasi, 34.

Telekomunikasi Selular. (2017): Syarat Dan Ketentuan Layanan LINKAJA [Online] Tersedia:

https://www.LinkAja.id/terms_conditions 